\title{
10. Congresso Brasileiro de Saúde Coletiva
}

O 1 ? Congresso Brasileiro de Saúde Coletiva, promovido pela ABRASCO, no Rio de Janeiro, de 22 a 26 de setembro de 1986 , reuniu cerca de 2.500 pessoas das diversas profissões da saúde, provenientes de todos os Estados brasileiros, para debater o tema central do evento: Reforma Sanitária e Constituinte, Garantia do Direito Universal à Saúde.

Foram desenvolvidas 9 mesas-redondas e conferencias, 15 comunicações coordenadas e 20 cursos em torno do tema, tendo sido apresentados 170 trabalhos científicos na sessão de Temas Livres.

Abaixo, encontra-se a íntegra da Declaração Final do Congresso, aprovada na plenária final:

\section{DECLARAÇÃO FINAL DO \\ 1 ? CONGRESSO BRASILEIRO DE SAÜDE COLETIVA}

O 1 ? Congresso Brasileiro de Saúde Coletiva, promovido pela Associação Brasileira de Pós-Graduação em Saúde Cole. tiva, realizado no Rio de Janeiro, de 22 a 26 de setembro de 1986, com a participação de 2000 profissionais da área da saúde coletiva, oriundos dos diversos Estados, representa avanço significativo da Reforma Sanitária Brasileira:

- porque assumimos, na prática, a concepção ampla de saúde referendada na VIII Conferência Nacional de Saúde e alcançamos incorporar, ao campo da Saúde Coletiva, áreas do conhecimento imprescindíveis à plena realização do direito à saúde;

- porque fomos capazes de criar propostas técnicas que representam estratégias concretas da implementação das transformações necessárias à criação de um sistema único de saúde, de caráter estatal, descentralizado e controlado pela sociedade, equânime e universalizado no atendimento integral às reais necessidades da população;

- e porque, neste evento, foi reafirmada a unidade de todas as forças progressistas em torno das propostas aprovadas na VIII CNS e foram construídas e fortalecidas estratégias políticas necessárias à condução correta de nossa luta pela transformação do alarmante quadro sanitário e do caótico sistema de saúde com que convivemos nos dias atuais.

Nesse sentido, não basta apenas afirmar que a saúde deve ser entendida de forma ampliada como uma adição de diferentes elementos que a compб̃em, mas sim compreendê-la como um processo social, produto do perverso modelo de 
acumulaçao capitalista de uma sociedade estreitamente dependente do capital estrangeiro. Modelo esse que se traduz ein profundas e inaceitáveis desigualdades sociais, exemplificadas nas questões da posse da terra, da forma predatória de exploração da força de trabalho, das condições de vida urbna e rural.

Essa realidade espelha-se na incidencia cumulativa de doenças características do subdesenvolvimento e do desenvolvimento desordenado, que perversamente vitimam a classe trabalhadora. As políticas de saúde das últimas décadas não incorporam o conhecimento técnico e científico disponível, capaz de sanar grande parte desses males, porque se subordinam aos interesses capitalistas de acumulação e privatizaçao da saúde.

O processo de redemocratização do país, em que pesem as propostas de transformações objetivando o resgate da dívida social, não logrou os esperados efeitos sobre os setores sociais. Isso porque as políticas sociais continuam sendo equacionadas a partir de critérios de eficiência econômica e como mera decorrência de investimentos do setor produtivo da economia, enquanto a nossa riqueza continua a ser canalizada para o pagamento da dívida externa. Acresce-se a isso o deliberado sucateamento do setor público, que serve como justificativa de uma falaciosa concepção da natureza intrinsicamente ineficiente desse setor.

As possibilidades de reversão desse quadro implicam a contínua mobilização e organização das forças sociais com. prometidas com a luta pela implantação de uma Reforma Sanitária e pela garantia constitucional do direito à saúde como dever do Estado.

A ABRASCO se alia a todos aqueles que almejam a democratização da saúde e acredita que só através da nossa organização coletiva alcançaremos legitimar as medidas que avançam na direção da Reforma Sanitária e impedir, com a nossa vigilância constante, qualquer retrocesso no curso desse processo

Nesse sentido, reafirmamos:

- a necessidade da continuidade no processo de mobilização social em torno da Reforma, iniciado com a VIII CNS;

- o apoio à Comissão Nacional da Reforma Sanitária para que esta se legitime e ganhe força, para propor as transformações que se fazem necessárias;

- o apoio estratégico aos avanços representados pelas AIS enquanto um passo na valorização do setor público e o decidido repúdio a medidas privatizantes como o Cheque Consulta, que representam um retrocesso inaceitável no processo democrático na saúde;

Cadernos de Saúde Pública, R.J., (3):382-384, jul/set, 1986. 
- a necessidade de construção de uma Frente Popular pela Reforma Sanitária, capaz de organizar a base social e política que viabilizará as mudanças requeridas;

- e o nosso engajamento decisivo no processo constitucional, estabelecendo um projeto para a área de saúde a ser inscrito na Nova Constituiçao e comprometendo desde agora os candidatos com as propostas da Reforma Sanitária.

O 1 . Congresso Brasileiro de Saúde Coletiva não se encerra em si mesmo. Continuaremos mobilizados e organizados na difusão da nossa proposta para os constituintes, para os pro. fissionais, para toda a sociedade. Utilizaremos todos os instrumentos que dispomos para aumentar nossas forças e preservar nossa vigilância crítica.

Nesse sentido, recomendamos que sejam organizados foruns de debate e mobilização em todos os cantos do paŕs, articulando, assim, as representações dos trabalhadores, comunidade, instituições, partidos políticos, universidades, etc, a nível local, municipal e estadual. Desta forma, concretizaremos ainda mais a discussão sobre a Reforma Sanitária, conquistando o necessário respaldo organizativo da sociedade para a sua definitiva implantação.

Plenária do

19. Congresso Brasileiro de Saúde Coletiva 